CHAPTER SIXTEEN

\title{
FROM TRADE MONOPOLY INTO NARCO-STATE MONOPOLY
}

\begin{abstract}
The Javanese are a stupid race and, coveting the wealth of Europeans, have gradually fallen into their snare; but who could have calculated on the conquerors proceeding to invent the black fumes of opium, to tempt and delude the natives; urging them to consume this drug as a luxury, until they became so weak and emaciated, so dispirited and exhausted, that they could no longer think of regaining their land, nor conceive the idea of revenging their wrongs. The Javanese ... were readily overcome by this poison, and lost all care for themselves; but we Chinese, of the central flowery land, have also been deluded by them; for no sooner do we partake of this substance, than we lose all anxieties about our native land, have no further concern for father or mother, wife or children, and are plunged into unspeakable misery.
\end{abstract}

Ong-Tae-Hae (1791), p. 18.

Ong-Tae-Hae's criticism and self-criticism form a worthy conclusion to the previous chapter and probably the earliest forecast of what the Chinese could expect from the Western opium imperialism.

Raffles and his investigator, the famous John Crawfurd, were well aware of this fate. In that year, Raffles explicitly planned an opium-free Singapore! However, they could not repair the damage, only make reports for the bureaucrats and the later historians. Crawfurd prepared a rather hysterical report for Raffles about the latest revolt in which a Chinese landlord and opium farmer of several districts played a major role. Arrogant and without reservation about the British role as colonizer, he documented at the beginning of the English-Chinese century how the Chinese had remained again in an "intermediate position", leading to death and destruction from the end of the former Dutch century.

The climate was created in which the victims were lumped together and accused of being agents of the inimical competitors, the Dutch, of possessing all possible wealth, etc. The Chinese-I repeat Raffles' phrase- 
became a very dangerous people, and are to be remarked as a pest to the country; and that there appears to be no radical cure for this evil but their extermination from the interior, a measure which cannot now be effected. ${ }^{1}$

This is the irresponsible language of European authorities preparing the crowds for pogroms.

\section{A Transformation from Private into Public Interest}

After the internal assault by the Amphioen Society, the loss of the profitable Dutch opium position in Bengal or the Pyrrhus victory in Eastern Java, there followed a failed Dutch-English war (1795, loss of Ceylon) and the Napoleonic wars: the VOC broke down, and the Dutch state in Europe lost its independence. There was even a large opium debt owed to its main competitor, the EIC. In short, it was an easy job for the British to conquer Java and, therefore, "inherit" the rest of the East Indian archipelago.

In both the English and the Dutch case, it was not clear whether all this concerned a general public or a private interest. Both were on the brink of being drastically transformed; a most fundamental change took place now in the general opium history as well. Contrary to the Dutch situation, there was a flourishing private country trade apart from the EIC which formed a substantial 'Indo-British power at sea'. ${ }^{2}$ Around 1790 at least 70 ships from different countries called at Cochin. They were equivalent to 27,000 tons of shipping manned by 4000 lascars (hired Indian seamen) and defended by 564 guns. Their opium trade to China was worth thirty lakhs of rupees (3 million rupees) annually around 1800 and the trade in other goods, about twenty lakhs.

Certainly, there existed in the 18th-century something like a private Dutch "burgher" trade which was active around India and Ceylon or the Strait of Melaka. The few data are not very impressive and found in obscure literature; this trade does not exist in the official historiography, let alone it offers competition with the British trade. ${ }^{3}$ Although we only deal below with the Dutch case (for the English, see ch. 6), both remained closely connected at least until 1816 (for details, see Appendix 4).

\footnotetext{
1 Quoted from Raffles' Memoirs by S. Alatas, p. 29.

2 H. Furber, p. 181.

3 In F. Gaastra (1991), for instance, nothing is mentioned.
} 
To avoid a transfer into British hands, the new Dutch government took over all the VOC shares. This was similar to a nationalization of a private business. In the same stroke the Dutch state became the holder of an opium monopoly and started to produce and distribute opium itself. What does this mean and what are the implications?

First, that the Dutch government in Holland bluntly claimed herewith the "ownership" of the VOC "possessions". This was generously perceived as the entirety of the East Indies archipelago, a territory as large as the USA now! The VOC's personnel was, furthermore, transformed automatically into a state bureaucracy. It was like a Trojan Horse to accept this band of fully corrupt foreigners and set them to govern the East Indies from now on.

In hindsight, this was a rather absurd constellation. After creating a mess with the VOC or in East Java, some state in Western Europe, smaller than West Java alone, and after itself being occupied by a foreign power (Napoleonic France), claimed out of the blue the function of feudal overlord over all the kingdoms in this realm and was held responsible for law and order in this vast realm of a thousand islands. This claim was also clearly in variance with new enlightened ideas about colonialism, slavery, industrialization and all that, which were established in this period of the American and French Revolutions. Indeed, this move resembled a Napoleonic Restoration.

It concerned nearly five million people in Java and Madura alone, of which $2 \%$ was Chinese. What were called "European capitals" had 60,000 inhabitants (Batavia and suburbs), Semarang and Surabaya (each about $\left.20,000^{4}\right)$.

In France or Holland at the time, one could have enlightened ideas about, for instance, the abolition of slavery. However, in the East every Dutch man and woman had several slaves at their disposal. In Batavia 19,000 slaves lived, mostly coming from Bali and Celebes; in Semarang, about 4000 and in Surabaya, 3600. ${ }^{5}$ From Bali an estimated 1000 slaves (sapangan) were exported each year (from $165^{0}$ to 1830 some 150,000 of them were taken away from this island alone) ${ }^{6}$

There was not only a close connection between Dutch repression and indigenous slavery, but also between opium and slavery. The imported opium by the Dutch generated a chain of misery. The indigenous nobility

\footnotetext{
4 Th. Raffles, vol. 1, p. $61 \mathrm{ff}$.

5 Idem, p. 76.

6 H. Schulte Nordholt, p. 41; see also p. 43-44, p. 96.
} 
started wars to get prisoners, put their people in debt for the same reason, while convicts were mostly sold off. But the background of this is revealed in the following statement of a Balinese nobleman (the patih of Karangasem):

We wage war upon the others when we, lords, lack money; at such times we swoop down on the weakest of our neighbours, and all prisoners and their entire families are sold as slaves so that we ... have money to buy opium. ${ }^{7}$

That is the clearest perversion of life brought by the Dutch exploitation of these islands when they addicted the nobility and enslaved the common folk. Gradually, the use of opium by other people who had money became apparent in the course of the 19th-century as the Dutch pressure to increase opium consumption became stronger and more systematic thanks to the enlightened Europeans and Daendels' opium dens.

In other words: from about 1795-1815 the excessive Western private narco-military exploitation of a foreign territory by slavery and opium, supported by a foreign public institution (the Dutch state), was transformed into a foreign public narco-military exploitation of a foreign territory by "free slavery" and opium, sometimes mainly exercised through foreign private interests.

A new phase of Western imperialism started: the European Dutch government began to conquer a foreign territory, which was exploited just in the previous period. When this foreign power finally had to leave the territory forever, through the lost war of 1945-1949, the conquering of this socalled "colony" remained unfinished. ${ }^{8}$

7 Idem, p. 41.

8 The newest Dutch political-legal analysis of the Dutch exploitation of the East Indies, J. Somers, is still unable to acknowledge the illegal character (in all respects) of the Dutch activities in this part of the world, 6 o years after the war of liberation of the Indonesians. This should be the starting position for this kind of analysis. Then one can provide an explanation of why a permanent state of war was necessary from the start until the very end, with one massacre after another at regular intervals: in every part of the archipelago and in every period of these Dutch exploitative activities, people, tribes, and governments of indigenous states revolted against the white intruders. Now, Somers, does not argue against the dubious claims of the VOC Directors in the beginning of his history and ultimately supports the view that the present Indonesia was a creation of Dutch imperialism. For my view on imperialism, Martin Shipway's approach is much more interesting, although it does not go far enough. Disappointing in these respects is also H. Fischer-Tiné, M. Mann (ed.), in particular Mann's confinement to the reproduction only of the "civilized ideas" of Hastings and Cornwallis and to British ideas, without any moderation or investigation into the attitudes of the victims of these ideas. 


\section{The Four Van Hogendorps as Opium Dealers}

What about the implementation of this transformation? In the Netherlands the fate of the suspect and influential Van Hogendorp family symbolizes this rigorous change in a most perfect way. ${ }^{9}$ The father, William, (1735-1784) lost the largest part of his fortune through investments in the EIC. He went to the East Indies to become rich again and obtained lucrative bureaucratic positions. He had his own ship and "officially" smuggled opium worth a substantial fortune. On his return trip to a fantastic retirement in Holland, he drowned near the Cape of Good Hope. People stated: the ship had to sink because W. had too much gold on board. On Java, William was not only busy gathering a fortune in vain, but for some reason he supported smallpox vaccinations for the indigenous people. Furthermore, he was the first Dutchmen who attacked slavery and proposed to change this into a free labor relationship still within a colonial context.

William's eldest son, Dirk, was first and foremost a soldier; first a Prussian officer he ultimately became a Napoleonic general! Before he took this step, he went to the East Indies, where he fought in several of the many revolts against the Dutch repression in Malakka and the Riouw archipelago (1784). In Batavia he tried to re-organize the Dutch army. People laughed at him and, fully disappointed, he became one of the fiercest critics of the corrupt VOC elite.

In 1786 Dirk acted, however, as merchant in Bengal (Patna): at that time people came here for no other reason than to make a fortune with opium. Indeed, Dirk expected to leave the place with at least 100,000 guilders; he was not as greedy as colleagues, who returned home with millions. ${ }^{10}$

Back in Batavia Dirk was appointed commander of the military operations in eastern Java (Oosthoek; 1794). A highly critical report about the VOC Government in Batavia (particularly the main official, Nederburgh) and about the opium business led to his imprisonment. He could flee, however, went to Holland and published his critical report. He formulated a very liberal program for the "colony": the indigenous people were not lazy, they must be allowed private property (something which was unknown anyway), no slavery, no opium, no special emoluments for the

\footnotetext{
9 For the following see the biographies in E. Du Perron, p. 284-304; E. Vanvugt (1985), chapter 12; F. Gaastra (1991), p. 100 ff.; J. Somers, p. 82 ff.

10 F. Gaastra (1991), p. 100.
} 
Dutch bureaucrats ... In short, he propagated free labor in order to receive the blessings of an enlightened colonial regime; a progressive program which was never realized.

When the Netherlands were fully occupied by Napoleon, Dirk joined the army even after the Emperor "came back" to be defeated at Waterloo. This rather fanatic collaborator with the French occupier appears in Napoleon's testament! All this made him rightly and officially a traitor to his country.

William's second son, Gijsbert Karel (1762-1834), underwent a military training in Berlin together with Dirk, but choose to become a lawyer and ended up as a gifted organizer of the new Dutch state and colony. Gijsbert Karel and two other aristocrats stood at the founding of this state. After the disappearance of Napoleon, these three staged a coup (1813) to establish a Dutch kingdom for the first time in history, slightly less autocratic than the previous regime. This "out of the blue king", William I, was the son of the last stadhouder, William V the Fat, who garnered an opium fortune through the Amphioen Society. William I not only inherited this opium money (see ch. 17) but could easily be called the First Opium King, as will be revealed below.

Gijsbert Karel became the prime minister of this autocratic king and main supporter of a newly organized opium trade in the East Indies. This lead to an unprecedented exploitation of the East Indies, new, devastating wars and excessive profits from the opium business. It was the parallel development of what happened with the new opium policy in China exercised by the British Empire. Gijsbert Karel was strongly influenced by the British experiences and by Crawfurd's and Raffles' histories of the Indies archipelago. ${ }^{11}$

In the last volume of his famous Contributions, Gijsbert Karel gave a long historical analysis of the Dutch assault on the East Indies. ${ }^{12} \mathrm{He}$ described how the Portuguese were conquered; how the Dutch skillfully applied the European principle of balance of power in the East Indies between the different peoples and competitors (the divide and rule principle); how the most important task — 'to capture all the costly goods and manufactures'- was solved. In particular, he stresses the transformation of the private EIC into an activity of the British Crown, which had to stimulate the activities of the private merchants. The trade of the latter could not be stopped by the EIC: now this "private" trade was much larger than that of the EIC.

11 G. K. van Hogendorp, vol. IV, p. 1-14; VII, 339, 370 ff., $381 \mathrm{ff}$.

12 Idem, vol. X, p. 1-110. 
The fundamental global changes are indicated by the author as follows after concluding that the EIC was left only with an opium monopoly on the Chinese trade:

... it is common knowledge that it compensated the losses in all other branches of its trade with the profits of this monopoly. One of the most remarkable effects of the free traffic and trade is ... that the cotton wares are not going anymore from India to England but the reverse ... In a short time the English factories, by means of machines, are able to provide the whole world with cotton goods, while the cheap Indian labor has become obsolete through the technical innovations. ... England even makes the cotton products for the Indian people ... Through the way of life of the English in India ... the English taste in clothing, furniture, ornaments ... is spread among the sixty to one hundred million souls of the British Empire in Asia ... The profits and advantages are so enormous ... and the national interest is so well served, which could never have been the result of whatever balance in one's favor of a commercial company [like the EIC]. At the same time that the British Empire developed in this way, the Dutch society gradually declined ...13

According to Van Hogendorp the main reason for this decline was the personal interest of governors and officials which prevailed over the general interest of the Company, the VOC-EIC. A second reason was that the production and running costs of these companies were much too high in comparison to the English and later the American private trade. Also, the Dutch could not stand this private competition. In addition, the monopolies of the Dutch had a negative effect on the 'civilization of the indigenous people, while the new system of free trade, accepted by the English, enhanced the civilization of these people, and derives huge profits and commercial advantages even from this civilization. ${ }^{14}$ The long war with England from 1795-1813 was the death blow for the Dutch 'possessions' in Asia.

After this conclusion, Gijsbert Karel van Hogendorp provides a key confession, because he was personally responsible for staging a coup. The "we" in the quotation has, therefore, a special meaning in what follows about his own time:

Now everything is quiet in Europe, we got our independence back, and England returned our East Indies possessions ... Now we have done what England intends to do, but not realized fully at present. We have consigned the government of the Dutch Empire in Asia to the care of the Crown, with

13 Idem, p. 8, 9. See also vol. VII, p. 355 ff.

14 Idem, vol. X, p. 12. 
a specific exclusion of all Companies, and we have freed the travel and trade, not only for our own subjects, but also for all foreign people through payment of heavier import and export duties. What is left of the monopoly consists of the spices and nutmeg from the Moluccan islands and of the trade with Japan ....

In fact, he is proud to have reorganized the Dutch-Asian "possessions" into what could be called for the first time a "colony". This was done in close collaboration with the British. ${ }^{16}$ As could be expected of a Van Hogendorp, the first thing he mentions is:

Our armed forces, at sea as well as on land, are substantially larger than they were any time in the past. All the costs of the Government and this army and navy are paid from regular taxes in the possessions itself, so that they do not bother the State ... Our own [Dutch] surplus population can find a way out as soldier or sailor... The more these countries flourish, the more they can contribute to this Government and Army.... Our civilized Government is able to bring these people into a state of civilization ... our armed domination is compensated through civilization. ${ }^{17}$

The indigenous population had to pay for its own repression and what that meant was very soon crystal clear. He himself 'has much heard about revolts ... in the Moluccas ... Java ... Cheribon ... Sumatra ... Palembang ... Maningkabo ... West coast Borneo ... Celebes ... at present, we directly govern these countries. This method of conquering is nothing new, not for us and not for the English ...'18

Indeed, nothing new under the sun, except that this sun burns in Asia much harder: in the VOC period, the Dutch lived and acted from some bulwarks on the coasts of Java; now a regular conquering of all lands and islands was started. The legitimation (these people live under despotism, we bring civilization) was quite new: in Van Hogendorp's time Hegel was still alive, who invented the theory (not the word) of Oriental Despotism. ${ }^{19}$

15 Idem, p. 12, 13 .

16 It was clear that it was "physically impossible" for the English to occupy the East Indies archipelago as well. In addition, they needed the support of the Dutch in Europe to form a buffer-state against France; the new King William I also became king of what was later called "Belgium". Result: there was an exchange of British with Dutch "possessions" in Asia (for instance, Cape of Good Hope or Singapore became British; Bencoolen on Sumatra Dutch, etc.); several treaties between the countries were concluded which, indeed, resulted in peace after two centuries of sometimes severe wars. G. K. van Hogendorp was the author of these treaties as Minister of Foreign Affairs and many other functions.

17 Idem, p. 40, 41.

18 Idem, p. 42, 44.

19 See the really poor treatment of this concept in M. Mann's contribution to H. Fischer-Tiné, M. Mann (ed.), p. 5 ff., 29 ff. See H. Derks, 1978-1+2. 
The colony had to pay for itself; the state in Europe wanted to receive only the profits. One problem remained for the Western foreigners. This did not concern the indigenous people, who could be killed, but the English and American merchants. They had already established commercial houses in Batavia and other places. It was not proper to kill colleagues, as happened in an earlier period. There was now "free trade" in which the Dutch merchants seriously lagged behind. During the Raffles period the English had greatly extended their earlier "smuggling" practices, while the Dutch were absent.

In addition to their manufactures the English also imported here amphioen from Bengal, which is used and demanded there generally among the people like tobacco in Europe ... in particular, the island of Singapore is transformed into a port, roads, market with the best and most spacious buildings ...20 These examples are sufficient for Van Hogendorp to realize how the English got their profits 'and that we have to learn how the Dutch could get their profits ... We have everything that the English possess ... and we can speculate on the needs of the indigenous as the English have done. ... Do we need amphioen to add to our manufactures, we can buy it in Bengal, and we can buy it also in the Levant, where it seems to be much stronger.'21

The opium history of the Van Hogendorp family did not end with the important interventions of Gijsbert Karel. His son, also a William, asked his father (November 1826) why it was not possible to grow opium in Java itself. He pointed to an earlier Dutch initiative of investigating this possibility in Bengalen through the mission of a Frenchman Maurevert. This man had 'to collect amphioen and other seeds' in Bengalen and to advise about some poppy culture in the Dutch "possessions". ${ }^{22}$ Apparently son William planned such an activity on Java. Already half a year later (June 1827) he reported his father how some influential medical doctor had condemned it strongly. Apparently William's initiative fizzled out, but his obvious idea or initiative had a much longer life. Still an opium expert as the later Governor-General and Minister of the Colonies, Jean Chretien

20 G.K. van Hogendorp, vol. X, p. 5 o.

21 Idem, p. $5^{2}$.

22 Told and quoted by P. van der Kemp, p. 92. This M(e)aurevert was a draughtsman and botanist originally living in Pondicherry (East India). He was attached to the Dutch Natuurkundige Commissie (Commission for Natural Sciences) in the 1820s. M(e)aurevert was also known as collector of an orchid discovered on Java. Another Van Hogendorp (1812-1891), son of Dirk, was also active as administrator (resident) in several parts of Java. It is not known whether or how he supported the opium trade or consumption in the regions of his jurisdiction, Amboina, Semarang, Kadoe, Japara, etc. For these districts see chapter 20. 
Baud (1789-1859), is confronted time and again with the same advise. Another Governor-General, Rochussen, asked, for instance, his colleague and friend Baud whether he liked the memorandum of a former GovernorGeneral Van den Bosch in which the latter proposed to grow poppies on Menado (present North Sulawesi):

Before I read about the idea of Van den Bosch I myself studied the poppy culture of Bengal. We spend about a million to import the opium and there is, furthermore, the opportunity to export the own opium to China. Against this idea there are two questions: 1. Can all this succeed? 2. Is it clever to inform the population about a product which can be grown so easy and cheap, but which is so expensive for them to buy? ... ${ }^{23}$

Baud answered that his enemy in the colonial bureaucracy, the DirectorGeneral of the Ministry of Finance, proposed already in 1827 to grow poppy. There was as well an important advise of the President of the Royal Dutch Trading Company (see below), G. Schimmelpenninck: the opium culture is risky and we make much profit at the moment. In addition, it will be difficult to uphold our monopoly position thanks to the scattering of poppy seed. This man even argued that in this case the immorality among the whole population should increase. ${ }^{24}$

The above is enough to learn the mentality, ideology, role model and actions taken of/by the highest Dutch officials. Below, some details will be added to this.

\section{The Birth of a Narco-military State}

The Van Hogendorp family symbolized in the most perfect way how the excessive Western private narco-military exploitation of a foreign territory through slavery and opium supported by a state was transformed into a public narco-military exploitation through "free slavery" and opium mainly exercised by private interests. For the victims of this last new imperialism, the situation was not new, except that they soon learned about a much harsher opposition of the foreign military against their attempts to liberate oneself of Dutch oppression. Reason: this new state imperialism was accompanied by a much stronger Western military involvement in the foreign territories. Mainly the English and Dutch demonstrated this

23 J. Baud, J. Rochussen, vol. II, p. 24 (a letter from July 1845), p. 235 (a letter from April 1847). Jan Jacob Rochussen (1797-1871) was a Governor General as well.

24 Idem, vol. III, p. 5 and 9. 
policy. In addition, they promised each other in 1816 not to interfere in each other's territories. The French needed at least half a century to recuperate from the Napoleonic disaster and - in my view - they never succeeded (see part 4).

Stronger measures were also imposed to addict the population to amphioen/opium. Already during the "French" period of the East Indies, Governor-General Daendels (1808-1811) rationalized the distribution of opium and tried to stimulate its consumption. ${ }^{25} \mathrm{He}$ established for the first time many Government opium dens. Furthermore, he ordered every local commander, European or indigenous, to buy a sufficient quantity of opium for a period of six months on credit against a fixed price. The commander was allowed to profit as well from these activities. He also had to report under oath how the consumption in his district and local den(s) was structured. Failure to do so was punished with deportation. Small wonder that the opium income of the state multiplied nearly ten times in 1804 and more than doubled within two years (1809-1810; see appendix 4)!

Daendels' opium system was embedded in a new, typically French, hierarchical organization of the colonial state with the French-Dutch King Louis Napoleon at the summit; there was no place for indigenous princes anymore. They could become a prefect in this system of prefectures and keep their feudal rights, thus securing their income.

This new system of foreign exploitation was extended into more or less a slave state. The Javanese were obliged under harsh repression to plant coffee trees in every available spot. What Daendels introduced in the opium and coffee business remained more or less intact throughout the 19thcentury. He is, therefore, the one who established the main features of a narco-military regime. For the Javanese it was lucky that Daendels stayed only for a short period. Not that their situation improved much afterwards, but some enlightenment could be registered occasionally.

After this French-Dutch period, the East Indies fell prey to Raffles. His very English "liberal reform" was introduced, with its stress on private instead of public initiatives. Contrary to this English practice, however, the Dutch chose later for the combination of harsher military activities, stronger government regulations and privileged private entrepreneurship

25 For Daendels' opium measures, see Appendix 4; E. Vanvugt (1985), p. 134 ff. For his coffee culture and its effects, see J. Bastin, p. 62 and passim. Also, the article by M. Fernando and W. O'Mally in: A. Booth et al (ed.), p. 171-186. During the whole of the 19thcentury, nearly $50 \%$ of all agricultural households was employed in coffee cultivation. Multatuli's complaints about the Dutch 'robber-state' were based on the practices in this sector. 
in every product including opium. This was, in fact, a continuation of the Daendels system. How the other Van Hogendorps and their autocratic king fixed this situation will be the subject of the next two chapters. Here we follow in some detail how the transformation took shape in which opium played such a key role.

The first three Van Hogendorps, each in his way, were aristocratic children of the Enlightenment (like Daendels in fact). They subsequently demonstrated the phases which led to the autocratic leadership of Napoleon or the introduction of an autocratic kingdom of the House of Orange. They all expressed their anger about the highly stubborn, corrupt, selfish Dutchmen in the "colonies". The objects of this criticism were slavery and opium. Still, these Hogendorps were at the same time very anxious to amass fortunes in the opium business and/or to propagate opium on the largest possible scale as financial lubricant of the state. This points to the highest degree of hypocrisy. Since they all held important and leading positions, this hypocrisy immediately had rather severe, sometimes lethal consequences, at least for the millions resident in their Asian "possessions" and new conquests.

This hypocrisy of the Hogendorps was a general phenomenon from the beginning of the transformation period. There was, for instance, a commission installed to organize a new framework for the opium business now that the almighty position of the private VOC and its fully corrupt product, the Amphioen Society, had perished. Its president, Nederburgh, the mightiest colonial bureaucrat to date, was formerly a strong supporter of extension of the opium business of the private Amphioen Society. But now (1803) he subscribed to the

'state maxim ... it is not at all an injustice that the Colonies exist for the Motherland and not the reverse', and he also condemned the use of opium 'as a slow poison that undermines the mind as well as the body, while it makes in the end that men are not able to work and transforms them into animals. $^{26}$

The second part of the statement was an echo of his most sincere enemy, Dirk van Hogendorp. With this change of opinion, Nederburgh reproduced the position of the new state, which had to cater for several competing interests in the motherland. This lead to his quasi-above-the-parties position: the combination of the divide and rule and/or the enemy of your enemy is your friend maxims with the stiff-upper lip rule, what formerly

26 Quoted in E. Vanvugt (1985), p. 131. See also J. Rush, p. 136. 
were the bare facts can now be acknowledged and vice versa. A long-lasting conflict with Van Hogendorp was the result.

A bit later, the confrontation with the Raffles government and ideology had to be mastered. The new Dutch rulers knew Crawfurd's or Raffles' History ofJava (1817) by heart. Raffles even went to Europe and dined with G. van Hogendorp and King William I in Brussels (1817). He was not impressed:

[The] King himself, and his leading minister, seem to mean well, [but] they have too great a hankering after profit, and immediate profit, for any liberal system to thrive under them ... The King complained of the coffee culture having been neglected, and expressed anxiety that he should soon have consignments; and while he ... assured me that the system introduced under my administration should be continued, maintained that it was essential to confine the trade, and to make such regulations as would secure it and its profits exclusively to the mother-country. (italics of R.) ${ }^{27}$

A matter of greed for money: an English intellectual's judgment about a Dutch intellectual like Gijsbert K. van Hogendorp accentuates quite important differences.

The opium opinions and policies of King William I or the Van Hogendorps are now well-known, but what about Raffles in this respect? In his History ofJava, there is a special chapter on opium. It starts as usual from the wrong end: it had not been the Dutch and English monopoly and "smuggler" trade that had spread opium in the region, the indigenous people themselves were addicts by nature. He wrote:

The use of opium, it must be confessed and lamented, has struck deep into the habits, and extended its malignant influence to the morals of the people, and is likely to perpetuate its power in degrading their character and enervating their energies, as long as the European government, overlooking every consideration of policy and humanity, shall allow a paltry addition to their finances to outweigh all regard to the ultimate happiness and prosperity of the country. ${ }^{28}$

Raffles continued his text with a two-page quotation of Dirk van Hogendorp's anti-opium tract in which sentences appear like:

If a large quantity is taken, it produces a kind of madness, of which the effects are dreadful, especially when the mind is troubled by jealousy, or inflamed with a desire of vengeance or other violent passions. At all times it leaves a slow poison, which undermines the faculty of the soul and the

27 Quoted in J. Bastin, p. 66, 67.

28 Th. Raffles, vol. 1, p. 102, 103. 
constitution of the body, and renders a person unfit for all kind of labour and an image of the brute creation. ... To satisfy that inclination, he will sacrifice every thing, his own welfare, the subsistence of his wife and children, and neglect his work; so that, at last, he no longer respects either the property of life of his fellow creature ... no law, however severe, could be contrived ... to prevent at least that in the future, no subjects of this Republic, or of the Asiatic possessions of the state, should be disgraced by trading in that abominable poison. ... It is therefore necessary at once, and entirely, to abolish the trade and importation of opium, and to prohibit the same, under the severest penalties that the law permits, since it is poison. The smuggling of it will then become almost impracticable, and the health, and even the lives of thousands will be preserved. ${ }^{29}$

So, the highest officials of England and the Netherlands, the countries most involved in slavery and the opium trade in the world, knew perfectly well the kind of ravaging effects their activities had in their 'Asiatic possessions'. In England, at least, the anti-slavery movement succeeded at this time; the Dutch colonies were the very last in the world to prohibit slavery. The greed of the English (excessive among the Dutch elite) was inflamed to such a degree and the knowledge that opium was the best means to sustain the political peace in the 'possessions' meant that opium was never prohibited.

Dirk Van Hogendorp, Raffles and Gijsbert Karel accepted this as the most promising guideline to get as much profit as possible for both state and private merchants:

Opium is one of the most profitable articles of eastern commerce: as such it is considered by our merchants ... it is impossible to oppose trading in the same. In this situation of affairs, therefore, we would rather advise that general leave be given to import opium at Malacca, and to allow the expectation from thence to Borneo and all the eastern parts not in the possession of the state' (Italics of Raffles/Van Hogendorp). ${ }^{30}$

The maxim became, therefore, to direct the opium to those Asiatic regions not yet in the "possession" of some Western power: that became, of course, the advice to addict China on the largest possible scale. A variant with the same background is: the English government's opium trade would continue up to the gate to the East Indies, Malacca, where the Dutch would pick it up and distribute it themselves in "their" archipelago. That is what happened in fact. Anyway, it was the guideline which triggered the most

\footnotetext{
29 Idem, p. 104, 105.

30 Idem, p. 104.
} 
lucrative opium deals in world history for the Dutch as well as for the English.

The target of the English was China rather than its own colony of India, the production center. The Dutch government had a quite different interest: it directed the poison to its "own subjects" in Asia who were apparently not yet "pacified" enough. After China the East Indies became the largest consumption center thanks to the continuous efforts of the Dutch and their supporters.

The Dutch had nothing to sell in the East Indies except opium. Java and the whole archipelago were to become the sole producer of export crops and mining resources; the indigenous chiefs had to be bound to deliver for the lowest possible prices; from this income they could also buy Dutch opium and later "batiks" fabricated by the Dutch industry in Holland.

This transformation of the VOC + informal governmental support into formal Dutch government opium business is reproduced in Baud's table of the years 1746-1816 (see Appendix 2). However, the "new" knowledge about the poisonous character of opium led to one argument and one conclusion: of course, the colonial state must abandon its involvement with the opium business, but-alas - the English competition was so tough that the compulsory deliveries of the other classical colonial products (coffee, pepper, rice, wood, etc.) should be retained because 'they belong essentially to the Javanese manners and customs'! In short, the opium business had to be continued as usual and extended if possible because it was one of the few profitable ventures.

What is the reality behind these declarations and plans? The British part of this business was characterized in those years by the position of Raffles lying between the interests of the EIC-British government in India and his own interests in Java. "India" expected to transform the new British 'possession' into an easily exploitable producer of agricultural products by indigenous producers. Raffles wanted to go much further: the whole feudal structure with its indigenous nobility had to disappear in favor of a money economy and a direct relationship between the government and peasants in order to make the East Indies also into a market for British manufactured products.

To pay for the occupation of Java, etc. "India" wanted to create a land revenue based upon the principles of free cultivation and free trade, whereas Raffles looked first for commercial and next for territorial revenue. ${ }^{31}$ He promised "India" (January 1812) much rice and coffee, Banca tin

31 J. Bastin, p. 17 . 
and spices. He furthermore expected that his opium monopoly would yield 700,000 Spanish dollars (= ca. 2 million Dutch guilders). Together with revenues from customs and taxes, this could bring the government's income to 5.3 million Spanish dollars (= ca. 15 million Dutch guilders). He only arrived at half this target, and his position versus "Calcutta" was undermined:

... the severest of all financial shocks was the abolition of the Java opium monopoly in favor of free importations by Calcutta merchants. The Bengal Government had taken this action in the belief that ultimately the Company would gain more from Calcutta sales by opening markets in the Archipelago than from any local monopoly in Java.... The loss of the opium revenue and the failure of external commerce led to a big increase in the export of specie from Java by the Bengal merchants ... The result was that the continued adverse balance of trade led to a spectacular flight of specie from the island during the second half of $1812 \ldots{ }^{32}$

The Chinese later experienced exactly the same process for the opiumsilver exchange with the English smugglers from India (see ch. 6).

The consequence was also that Raffles' anti-opium and anti-slavery policy in Java (whatever its dubious performance) was definitely abandoned. In reality, the old VOC practice, renewed by Daendels, was restored in a pro-slavery and pro-opium fashion. Anyway, a policy was introduced

thanks to the acceptance of the system ... to make the opium farming as profitable as possible for the colonial treasury' and to expand the lease system also into the Outer Districts. ${ }^{33}$

Before 1800 the tendency was to stimulate opium consumption gradually and to ask low prices in order not to trigger smuggling. Indeed, this approach was definitely abandoned: now, the aim was big money in the shortest possible time and with the most effective methods. At the start, the government targeted three million Dutch opium guilders annually for itself and envisaged a profit of four million for the farmers.

Why? Its new aim of conquering the whole archipelago and colonizing this huge territory on land and at sea had to be paid for by the 'Asiatic pos-

32 Idem, p. 18, 19. The contradictions in Raffles' opium policy are, in fact, more remarkable. During Daendels' regime the opium income came to $16 \%$ of the total. Officially (that is to say: according to his own statistics) Raffles diminished this percentage to 12.3 (1812/13), to $13.4(1813 / 14)$ and then even to $5 \cdot 7$. However, not only his land rent income doubled during his regime and the leases increased in a substantial way, but the opium import increased in 1812-1816 from 40,500 chests to 73,250 (see appendix 2 ). This is clearly in variance with his own statistics.

33 J. C. Baud, p. 161. 
session' itself. It was, furthermore, a task which had to be exercised by the Dutch state-in-the-new-colony in close cooperation with specific private interests.

How this was done in the 19th-century is recounted here in two stories. A first short story tells about how tin was mined on the island of Billiton, in which the private initiative (the Billiton Mining Company) was stressed, and the government tin exploitation on the neighboring island of Banca remained more or less in the background. The second, longer story demonstrates in a rather spectacular way how the public-private cooperation has lead to the activities of a state-within-the-state, the Royal Dutch Trade Company. In both stories opium plays an important, but different, role, and in both stories the same is true for the new Dutch royalty. 